HNF-EP-0702

Revision 1

\title{
Flammable Gas Project: Criteria for Flammable Gas Watch List Tanks
}

Prepared for the U.S. Department of Energy

Assistant Secretary for Environmental Management

Project Hanford Management Contractor for the

U.S. Department of Energy under Contract DE-AC06-96RL13200

Approved for public release; distribution is unlimited 
LFGAL DISCLANMER

This report was prepared as an account of work sponsored by an agency of the United States Government. Neither the

United States Government nor any agency thereof, nor any of their employees, nor any of their contractors, subcontractors or their employees, makes any warranty, express or implied, or assumes any legal liability or responsibility for the accuracy, completeness, or any third party's use or the results of such use of any information, apparatus, product, or process disclosed, or represents that its use would not infringe privately owned rights. Reference herein to any specific commercial product, process, or service by trade name, trademark, manufacturer, or otherwise, does not necessarily constitute or imply its endorsement, recommendation, or favoring by the United States Government or any agency thereof or its contractors or subcontractors. The views and opinions of authors expressed herein do not necessarily state or reflect those of the United States Government or any agency thereof.

This report has been reproduced from the best available copy. Available in paper copy and microfiche.

Available to the U.S. Department of Energy and its contractors from

U.S. Department of Energy

Office of Scientific and Technical Information (OST)

P.O. Box 62

Oak Ridge, TN 37831

(615) 576-8401

Available to the public from the U.S. Department of Commerce National Technical Information Service (NTIS)

5285 Port Royal Road

Springfield, VA 22161

(703) $487-4650$

Printed in the United Stotea of Americe

DISCLM-1.CHP (8-95) 
HNF-EP-0702

Revision 1

\title{
Flammable Gas Project: Criteria for Flammable Gas Watch List Tanks
}

\author{
G. D. Johnson
}

Duke Engineering \& Services Hanford, Inc.

Date Published

January 1997

Prepared for the U.S. Department of Energy

Assistant Secretary for Environmental Management

Froject Hanford Management Contractor for the

U.S. Department of Energy under Contract DE-ACO6-96RL13200

Approved for public release; distribution is unlimited 


\section{RELEASE AUTHORIZATION}

Document Number: HNF-EP-0702, Rev. I

Document Title: $\quad$ Flammable Gas Project: Criteria for Fiammable Gas Watch List Tanks

Release Date: $\quad 1 / 29 / 97$

This document was reviewed following the procedures described in WHC-CM-3-4 and is:

APPROVED FOR PUBLIC RELEASE

WHC Information Release Administration Specialist:

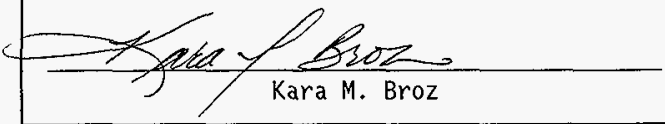


HNF-EP-0702, Rev. 1

\section{CONTENTS}

1.0 INTRODUCTION $\ldots \ldots \ldots \ldots \ldots \ldots \ldots \ldots \ldots \ldots \ldots \ldots \ldots \ldots \ldots \ldots \ldots$

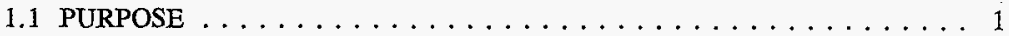

1.2 BACKGROUND $\ldots \ldots \ldots \ldots \ldots \ldots \ldots \ldots \ldots$

2.0 CRITERIA FOR FLAMMABLE GAS WATCH LIST TANKS . . . . . . . . 3

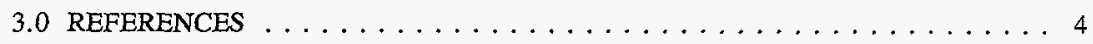
APPENDIX

A PUBLIC LAW $101-510 \ldots \ldots \ldots \ldots \ldots \ldots \ldots \ldots$ A 1 
HNF-EP-0702, Rev. 1

This page intentionally left blank. 


\subsection{INTRODUCTION}

\subsection{PURPOSE}

The Flammable Gas Watch List is the listing of tanks that are subject to the provisions of Public Law 101-510, Section 3137, "Safety Measures for Waste Tanks at Hanford Nuclear Reservation" (Appendix A). Tanks on the Flammable Gas Watch List are judged to have a serious potential for release of high-level waste due to the ignition of flammable gases released from the waste in the tank. The purpose of this document is to provide criteria for identifying and categorizing the Hanford Site high-level waste tanks to be included on the Flammable Gas Watch List. This document also provides criteria on which to base a recommendation to remove tanks from the Flammable Gas Watch List.

\subsection{BACKGROUND}

The potential for flammable and/or explosive conditions resulting from flammable gas (e.g., hydrogen) generation, retention, and release in high-level radioactive waste has long been recognized as a hazard. In 1990, the entrapment of large quantities of flammable gases within the waste of Hanford Site tank 241-SY-101 was recognized as a unique hazard requiring special attention and control. In April 1990, administrative controls were implemented for controlling activities within tank 241-SY-101 and other tanks that were identified as potentially having similar behavior (Bracken 1990). This was the first application of the term "Watch List" to Hanford tanks.

In May 1990, the U.S. Department of Energy, Richland Operations Office (RL), determined that the matter of hydrogen and nitrous oxide evolution within the material in certain waste tanks and subsequent hypothetical ignition was an unreviewed safety question (USQ) (Lawrence 1990). The USQ was applied to the tanks previously identified as tanks of concern in Bracken (1990).

In November 1990, Public Law 101-510 was passed. Section 3137 (Appendix A), also referred to as the Wyden Amendment, was part of this law. This section requires the Secretary of Energy to identify within 90 days which high-level nuclear waste tanks may have a "serious potential for release of high-level waste due to uncontrolled increases in temperature or pressure." Tanks were identified because they contained flammable gas, ferrocyanide, or organic chemicals, or because they had high radioactive decay heat. In January 1991, Westinghouse Hanford Company (WHC) formally submitted the Watch List of tanks subject to the law (Harmon 1991a). In February 1991, WHC submitted the selection methodology for flammable gas tanks (Harmon 1991b). This selection process was improved from the original 1990 process and two additional tanks were placed on the Watch List. Harmon (1991b) also included a proposed method for removing tanks from the Watch List. This Watch List identified 23 tanks subject to Public Law 101-510, Section 3137, because of 
HNF-EP-0702, Rev. 1

flammable gas hazards. In 1993, two additional tanks were added to the Flammable Gas Watch List (Fulton 1993, WHC 1993).

In August 1994, WHC issued Criteria for Flammable Gas Watch List Tanks (Hopkins 1994). Hopkins (1994) is superseded by this document, HNF-EP-0702, Revision 1. In addition, work controls to address flammable gas hazards have been implemented for all 177 tanks.

In October 1994, the U.S. Department of Energy, Headquarters, issued a memorandum providing guidance on modifications to the Hanford Site high-level waste tanks watch list (Lytle 1994). This memorandum stated that no laws or DOE Orders exist that establish the process or criteria for modifications to the Watch List. The memorandum further established that the Office of Environmental Management is the approval authority for modifications to the Watch List. Guidance was given that RL will discuss any proposed modifications to the Watch List with appropriate stakeholders.

\subsection{CRITERIA FOR FLAMMABLE GAS WATCH LIST TANKS}

The Flammable Gas Watch List is the listing of those single-shell or double-shell high-level nuclear waste tanks at the Hanford Site that may have a serious potential for release of highlevel waste because of uncontrolled increases in temperature or pressure. The Flammable Gas Watch List is specific to those tanks in which the initiating event of the uncontrolled increase in temperature or pressure is a potential for flammable gas combustion.

The selection criterion for the Flammable Gas Watch List is as follows:

Any tank that can have a flammable gas volume in the dome space that, when ignited, would result in pressure above a containment-related tank design limit will be categorized as a Flammable Gas Watch List tank.

The criterion for removing tanks from the Flammable Gas Watch List is as follows:

Any tank that no longer satisfies the selection criterion for the Flammable Gas

Watch List will be removed from the Watch List.

Analysis of tanks for gas release behavior must be based on a total reconciliation of all available data for the tank such that a consistent understanding of tank conditions is achieved. Once it is determined that a tank is a candidate for gas release behavior, the data must be assessed to determine that sufficient quality exists to perform quantitative calculations. Only when the data are deemed to be of sufficient quality will calculations of magnitude for potential gas release events be performed. 


\subsection{REFERENCES}

Bracken, G. J., 1990, Flammable Gas/Slurry Growth Issues, (letter to President, Westinghouse Hanford Company, April 2), U.S. Department of Energy, Richland Operations Office, Richland, Washington.

Fulton, J. C., 1993, Addition of Tank 241-AW-101 to the Flammable Gas Watch List, (letter 9354700 to R. E. Gerton, U.S. Department of Energy, Richland, Operations Office, June 3), Westinghouse Hanford Company, Richland, Washington.

Harmon, H. D., 1991a, Safety Measures for Waste Tanks at Hanford Site, Richland, Washington, (letter 9059124 to R. E. Gerton, U.S. Department of Energy, Richland Operations Office, January 8), Westinghouse Hanford Company, Richland, Washington.

Harmon, H. D., 1991b, Watch List for Tanks Which May Have Hydrogen Buildup, (letter 9001478B R1 to R. E. Gerton, U.S. Department of Energy, Richland Operations Office, February 8), Westinghouse Hanford Company, Richland, Washington.

Hopkins, J. D., 1994, Criteria for Flammable Gas Watch List Tanks, WHC-EP-702, Rev. 0, Westinghouse Hanford Company, Richland, Washington.

Lawrence, M. J., 1990, Unreviewed Safety Question - Waste Storage Tanks, (memorandum to L. P. Duffy, U.S. Department of Energy, Headquarters, May 14),

U.S. Department of Energy, Richland Operations Office, Richland, Washington.

Lytle, J. E., 1994, Action: Delegate Authority to the Office of Waste Management to Make Modifications to the Hanford High-Level Waste Tanks "Watch List", (memorandum to T. P. Grumbly, October 13), U.S. Department of Energy, Washington, D.C.

Public Law 101-510, 1990, "Safety Measures for Waste Tanks at Hanford Nuclear Reservation," Section 3137 of National Defense Authorization Act for Fiscal Year 1991.

WHC, 1993, 200 West Area Waste Tank 24I-U-107 Added to the Flammable Gas Watch List, Occurrence Report RL-WHC-TANKFARM-1993-0115, December 16, Westinghouse Hanford Company, Richland, Washington. 
HNF-EP-0702, Rev. 1

This page intentionally left blank. 
HNF-EP-0702, Rev. 1

APPENDIX A

PUBLIC LAW 101-510 (H.R. 4739), NOVEMBER 1990, NATIONAL DEFENSE AUTHORIZATION ACT FOR FISCAL YEAR 1991

Section 3137: Safety Measures for

Waste Tanks at Hanford

Nuclear Reservation 
HNF-EP-0702, Rev. 1

This page intentionally left blank.

A-2 


\title{
APPENDIX A
}

\section{PUBLIC LAW 101-510 (H.R. 4739), NOVEMBER 1990, \\ NATIONAL DEFENSE AUTHORIZATION ACT FOR FISCAL YEAR 1991}

\author{
Section 3137: Safety Measures for \\ Waste Tanks at Hanford \\ Nuclear Reservation
}

(a) Identification and Monitoring of Tanks. Within 90 days after the date of the enactment of this Act, the Secretary of Energy shall identify which single-shelled or double-shelled high-level nuclear waste tanks at the Hanford Nuclear Reservation, Richland, Washington, may have a serious potential for release of high-level waste due to uncontrolled increases in temperature or pressure. After completing such identification, the Secretary shall determine whether continuous monitoring is being carried out to detect a release or excessive temperature or pressure at each tank so identified. If such monitoring is not being carried out, as soon as practicable the Secretary shall install such monitoring, but only if a type of monitoring that does not itself increase the danger of a release can be installed.

(b) Action Plans. Within 120 days after the date of the enactment of this Act, the Secretary of Energy shall develop action plans to respond to excessive temperature or pressure or a release from any tank identified under subsection (a).

(c) Prohibition. Beginning 120 days after the date of the enactment of this Act, no additional high-level nuclear waste (except for small amounts removed and returned to a tank for analysis) may be added to a tank identified under subsection (a) unless the Secretary determines that no safer alternative than adding such waste to the tank currently exists or that the tank does not pose a serious potential for release of high-level nuclear waste.

(d) Report. Within six months after the date of the enactment of this Act, the Secretary shall submit to Congress a report on actions taken to promote tank safety, including actions taken pursuant to this section, and the Secretary's timetable for resolving outstanding issues on how to handle the waste in such tanks. 
HNF-EP-0702, Rev. 1

This page intentionally left blank. 
HNF-EP-0702, Rev. 1

\section{DISTRIBUTION}

$\underline{\text { Number of copies }}$

OFFSITE

3

U.S. Department of Energy

EM-38, Trevion II

12800 Middlebrook Road

Germantown, MD 20874

Harry Calley

Dave Pepson

Ken Lang

1

Argonne National Laboratory

9700 S. Cass Avenue

Argonne, IL 60439

Danny Meisel

1

Harry Babad

2540 Cordoba Court

Richland, WA 99351

1

David O. Campbell

102 Windham Road

Oak Ridge, TN 37830

1

Billy C. Hudson

202 Northridge Court

P.O. Box 271

Lindsborg, KA 67456

1

Thomas S. Kress

102-B Newridge Road

Oak Ridge, TN 37830

1

Thomas E. Larson

2711 Walnut Street

Los Alamos, NM 87544 


\section{DISTRIBUTION (Continued)}

Fauske and Associates, Inc. 16W070 W. 83rd St.

Burr Ridge, IL 60521

Marty G. Plys

Hans K. Fauske

G \& P Consulting, Inc.

3640 Ballard Road

Dallas, OR 97338

Arlin K. Postma

$\underline{\text { Los Alamos National Laboratory }}$ P.O. Box 1663

Los Alamos, NM 87545

W. L. Kubic K557

K. Pasamehmetoglu K555

C. Unal K575

1

Nuclear Consulting Services, Inc.

P.O. Box 29151

Columbus, OH 43229-0151

J. Louis Kovach

Oak Ridge National Laboratory

P.O. Box 2008

Oak Ridge, TN 37831-6495

Charles W. Forsberg, MS-6495

2

Sandia National Laboratories

P.O. Box 5800

Albuquerque, NM 87185

Dana A. Powers, MS-0744

Scott E. Slezak, MS-0741 
HNF-EP-0702, Rev. 1

\section{DISTRIBUTION (Continued)}

1

State of Washington - Department of Ecology

Alex B. Stone

1315 W. 4th Avenue

Kennewick, WA 99336

1

Westinghouse Savannah River Company

Savannah River Site 241-121H

Aiken, SC 29802

Susan J. Eberlein

\section{ONSITE}

12

U.S. Department of Energy, Richland Operations Office
M. H. Campbell $\quad$ 57-73
K. Chen
S7-54
J. M. Gray
S7-54
C. A. Groendyke $\$ 7-54$
M. A. Hunemuller S7-50
D. H. Irby
S7-54
J. K. McClusky S7-54
G. W. Rosenwald S7-54
C. L. Sohn
S7-51
Public Reading RoomH2-53
RL Docket File (2) B1-17

$\underline{\text { Hanford Contractors }}$

S. A. Barker

R2-11

W. B. Barton

R2-11

R. E. Bauer

S7-14

D. R. Bratzel

S7-14

R. J. Cash (3)

S7-14

A. F. Choho

H6-36

R. A. Dodd

S5-07

G. L. Dunford

A2-34

W. M. Funderburke

R2-38

T. C. Geer

R2-38

J. M. Grigsby

R1-49 
DISTRIBUTION (Continued)

R. C. Hill R1-51

K. M. Hodgson

$\mathrm{H} 0-34$

G. D. Johnson (10)

S7-14

N. W. Kirch

R2-11

J. G. Kristofzski

$\mathrm{R} 2-12$

C. E. Leach

R1-49

J. W. Lentsch

S2-48

J. E. Meacham

S7-14

W. H. Meader

S8-05

D. M. Ogden

H0-34

M. A. Payne

S7-84

L. D. Pennington

S7-21

D. A. Reynolds

R2-11

S. H. Rifaey

R1-56

W. E. Ross

S5-07

O. M. Serrano

R2-12

J. P. Sloughter

R2-54

J. S. Schofield

S7-12

E. R. Siciliano

H0-31

L. M. Stock

S7-14

A. M. Umek

S7-81

R. J. Van Vleet

A3-34

D. J. Washenfelder

S7-40

J. R. White

S7-15

J. H. Wicks

R2-50

N. E. Wilkins

R2-11

Central Files

A3-88

EDMC

H6-08

DPC

A3-94

\section{ONSITE}

Pacific Northwest National Laboratory

Z. I. Antoniak

K7-15

J. M. Bates

K7-15

J. W. Brothers

K5-22

S. A. Bryan

P7-25

D. M. Camaioni

K2-44

J. A. Campbell

P8-08

P. A. Gauglitz

P7-41

R. T. Hallen

P8-38 
HNF-EP-0702, Rev. 1

\section{DISTRIBUTION (Continued)}

J. L. Huckaby

K6-80

B. J. Palmer

K7-15

F. E. Panisko

K8-34

L. R. Pederson

K2-44

A. Shekarriz

K7-15

C. W. Stewart

K7-15

P. D. Whitney

K5-12

Hanford Technical Library

P8-55 